\title{
Embryo research faces a renewed ban in US
}

Washington. Following intense pressure from anti-abortion lobby groups, a committee of the US House of Representatives last week voted for a complete ban on research using human embryos at the National Institutes of Health (NIH).

The move has raised concern that the $\mathrm{NIH}$, worried about the political fate of its overall budget request, may not risk either encouraging or carrying out such research during the term of the current Congress.

$\mathrm{NIH}$ neither conducts human embryo research in its own laboratories nor funds researchers elsewhere to do so. But it has for several months been on the brink of releasing ethical guidelines for such research,

based on the recommendations of an expert advisory panel (see Nature 371, 370; 1994).

The guidelines would provide guidance to both clinicians and laboratory scientists, and would open the door for NIH to begin its own research under certain restrictions. In particular, the panel recommended that research on embryos should be limited to the first 14 days after fertilization, a point at which cells are undifferentiated and the primitive streak has not yet appeared. It also agreed that, in special circumstances, oocytes could be fertilized for the purpose of research.

The advisory panel's recommendations were passed to Harold Varmus, the director

\section{California drops affirmative actions}

San Francisco. Faculty members at the University of California (UC) were last week assessing the likely impact of a decision by the university's governing 'Board of Regents' to discard the use of 'affirmative action' in hiring and admissions.

Those who had worked for years to help develop opportunities for women and minorities in science formed part of the protest at the symbolic message of the new policy - even though they differed over whether it would mean fewer women and minorities in science-related departments.

"The harm is social harm," says Francisco Ayala, chairman of the American Association for the Advancement of Science, and a professor of evolutionary genetics at UC, Irvine.

The regents voted 14:10 against continuing affirmative action policies in admissions, hiring and contracts. University officials said the change would be felt most deeply at the undergraduate level, as the hiring of faculty members and postgraduates is left to individual departments.

Furthermore, the resolution approved by the regents excludes any changes that would lead to the loss of federal or state funds to the schools. All federal contractors are required to set goals for recruiting women and minorities.

As a result, Ayala says the student population is likely to remain largely unchanged, while at the faculty level affirmative action policies have taught recruiters to look harder in non-traditional places.

"We have come so far that I don't think [recruiting] will be affected," he says. But he adds that, while women have made progress in science and other fields, there are still few minority faculty members.

Nevertheless, Ayala accepts that the regents' decision is likely to have a significant symbolic impact, complaining that the regents did not seem to feel that the make-up of the student population should reflect that of the state of California. "If we reduce diversity, it will be very unfortunate, for all sorts of reasons," says Ayala.

Sherrie Wilkins, past president of the Palo Alto chapter of the Association for Women in Science, felt the decision would inevitably harm the ability of women and minorities to succeed in science, even though the university is still bound to affirmative action in hiring.

"It won't have an impact today or tomorrow, but it will have a long-term impact," says Wilkins, who serves as a hiring consultant for bioscience companies. She adds that women and minorities remain underrepresented in science, and will have to continue to struggle for equal representation for a long time.

She claims that, while making hiring and admissions decisions based solely on merit makes sense on the surface, many studies have shown that 'merit' lacks objectivity. "There are not enough people who feel that the genders are the same in terms of intellect, capability and logic," says Wilkins.

A university report presented to the regents two months ago estimated enrolment among ethnic groups would change dramatically without affirmative action. The report found that African-American enrolment could drop by $\mathbf{4 0}$ to 50 per cent to just 2.5 per cent of the total student population. African-Americans make up 7 per cent of the state's population.

Latino enrolment was predicted to fall by 10 per cent. As a result, said the report, Latinos will make up just 12 per cent of the University of California's population, even though they constitute 30 per cent of the population of the state.

In contrast, Asian-American enrolment was predicted to climb by 15 per cent to 25 per cent. As a result, Asian-Americans would constitute 30 per cent of UC students, even though they make up only 10 per cent of the population.

Sally Lehrman of NIH, last September. Many believe that his reason for not releasing them is the fear that the guidelines could provoke a backlash from conservative legislators in a Congress keen to make deep cuts in the biomedical research agency's budget.

Similar concern appears to have made the research community - unlike either clinicians or patients' groups - reluctant to try to protect human embryo research from the proposed ban, approved as an amendment to the \$61-billion appropriations bill for the Departments of Labor, of Health and Human Services and of Education.

Under the bill as approved by the House Appropriations committee, the NIH would be spared the deep cuts proposed on education, job-training and health programmes. Instead, it would receive a 5.7 per cent increase in 1996.

Research using live human embryos has some vocal opponents in Congress. Jay Dickey, (Republican, Arkansas), for example, who drafted the amendment along with Roger Wicker (Republican, Mississippi), described such research as "orwellian".

Dickey's proposal was among several added to the bill with the intention of curbing funds for abortion or family planning. He claims a further effect is likely to be felt in moves to reinstate a ban on federally funded fetal tissue research imposed by the previous Republican administration but lifted by President Bill Clinton in 1993. "We want to reclaim that ground," said Dickey.

The Dickey amendment banning embryo research was nearly undermined by an alternative proposal drafted by John Edward Porter (Republican, Illinois), which reflected an executive order issued in December last year by President Clinton (see Nature 372, 490; 1994).

In particular, Porter's amendment would have permitted federal funding for human embryo research, provided the embryos used had not been created specifically for research purposes. But a tied vote of $26: 26$ meant that the proposal was not adopted.

The decision has been criticized by at least one member of the advisory panel. "The irony is that the goal [of research using human embryos] is to help people have babies and avoid abortions," said Mark Hughes, chief of reproductive and prenatal genetics at Georgetown University.

The lack of both ethical guidelines and funding from NIH for such research means that it will continue to be funded privately. The research is conducted mostly by infertility clinics, and focuses primarily on ways to increase the success rates of implantation; it will continue to be driven largely by profit, and will continue to lack peer review. Hughes says that he had hoped that NIH's guidance "would spill over into the private sector". 